\title{
Intestinal paracoccidioidomycosis simulating colon cancer
}

\author{
Paracoccidioidomicose intestinal simulando câncer de cólon \\ Rubens Chojniak, René Aloisio da Costa Vieira, Ademar Lopes, \\ Joaquim Costa Altenfender Silva and Carlos Eduardo Godoy
}

\begin{abstract}
We report a case of intestinal involvement of Paracoccidioidomycosis, in a patient considered to have colonic cancer. The diagnosis of this mycosis should be considered when an abdominal mass associated with intra-lesional calcifications on X-ray is observed. CT scans increase the findings.
\end{abstract}

Key-words: Paracoccidioidomycosis. Colonic cancer. Computed tomography. Intra-lesional calcifications

Resumo Relatamos um caso de envolvimento intestinal pela Paracoccidioidomicose, em paciente considerado como portador de câncer. O diagnóstico desta micose deve ser considerado na presença de massa abdominal associada a calcificações intralesionais ao raio $X$. A tomografia amplia os achados.

Palavras-chaves: Paracoccidioidomicose. Câncer colônico. Tomografia computadorizada. Calcificações intralesionais.

Paracoccidioidomycosis (PM) is an important fungal infection caused by a dimorphic fungus, Paraccocidioides brasiliensis. It occurs mainly in Latin America, with an annual incidence from 1 to 3 per 100000 inhabitants in endemic regions ${ }^{10}$. Identification of the fungus in the tissue (paracoccidioidal granuloma) or culture of exudate establishes the diagnosis ${ }^{7}$.

This mycosis mainly involves lungs, lymph nodes, adrenal glands and the $\operatorname{skin}^{7}$. Intestinal involvement may be either asymptomatic or the symptoms might be similar to colorectal cancer (CRC), and it has an incidence of $2.7 \%$ to $28.4 \%$ of autopsies ${ }^{7}$. The Intestinal form has nonspecific radiographic aspects, although abdominal lymph node calcifications ${ }^{9}$ and annular stenosis ${ }^{2}{ }^{4}$ are suggestive of the disease. Computed tomography (CT) imaging has increased the chance of diagnosing intestinal PM, showing alterations only described previously by conventional radiography ${ }^{1234689}$, laparotomy ${ }^{29}$ or necropsy ${ }^{7}$. We will describe a patient with intra-lesional calcifications in a pseudo-tumoral form of PM. There is no previous description of ileocecal CT findings in the radiologic literature.

\section{CASE REPORT}

A fifty-seven-year old patient, from the state of Bahia, Brazil, had a two-year history of pain, together with episodes of diarrhea, and a 30kilogram weight loss. The patient denied fever or gastrointestinal bleeding, but during the last six months was experiencing pain in the right lumbar region. Physical examination revealed a hard, tender tumor, adherent to the deep planes of the

Departamentos de Imagem e Cirurgia Pélvica do Hospital A C. Camargo, São Paulo, São Paulo State; Departamentos de Cirurgia Oncológica e Imagem do Hospital Pio XII; e Laboratório de Anatomia Patológica de São José dos Campos, São José dos Campos, São Paulo State, Brazil.

Address to: Dr. Rubens Chojniak. R. Prof. Antônio Prudente 211, Liberdade, 01509-010, São Paulo, São Paulo State, Brazil.

Tel: 5511 3272-5142; fax: 5511 3272-0261.

Recebido para publicação em 23/12/98. 
right iliac fossa. There were no palpable peripheral lymph nodes. There was no family history of CRC. The patient referred having treated an oropharyngeal PM 15 years before the present condition.

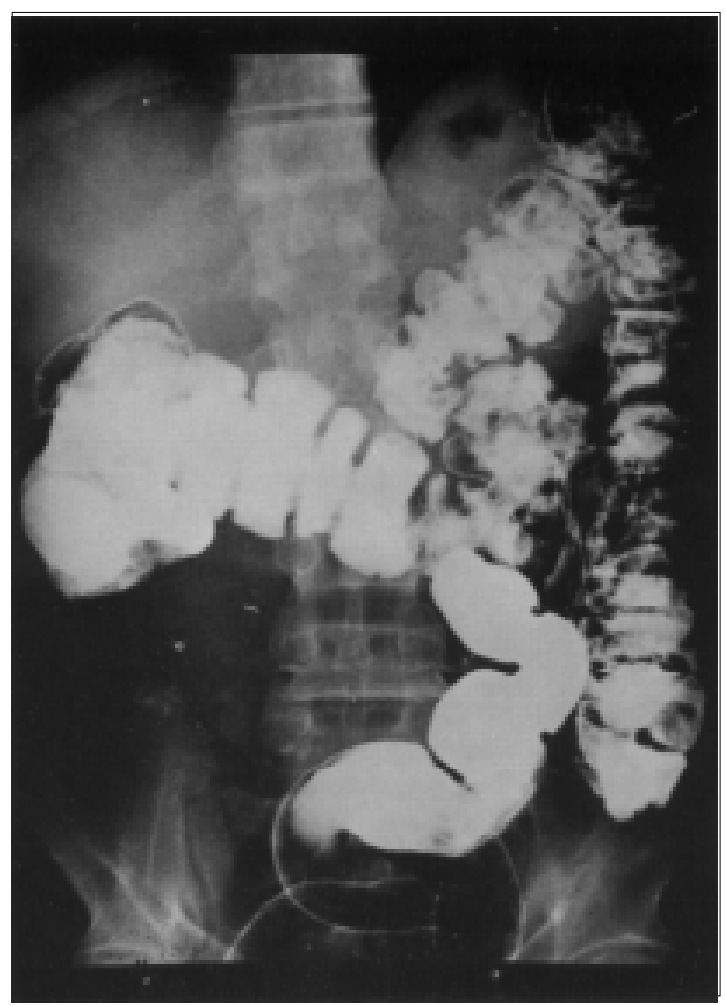

Figure 1 - Barium Enema: deformity of the cecum and presence of calcification in the right lower quadrant.
Of the imaging procedures performed, chest radiograph X-ray was normal. Alterations found in small bowel series, barium enema and abdominal CT are shown respectively in Figures 1, 2 and 3 .

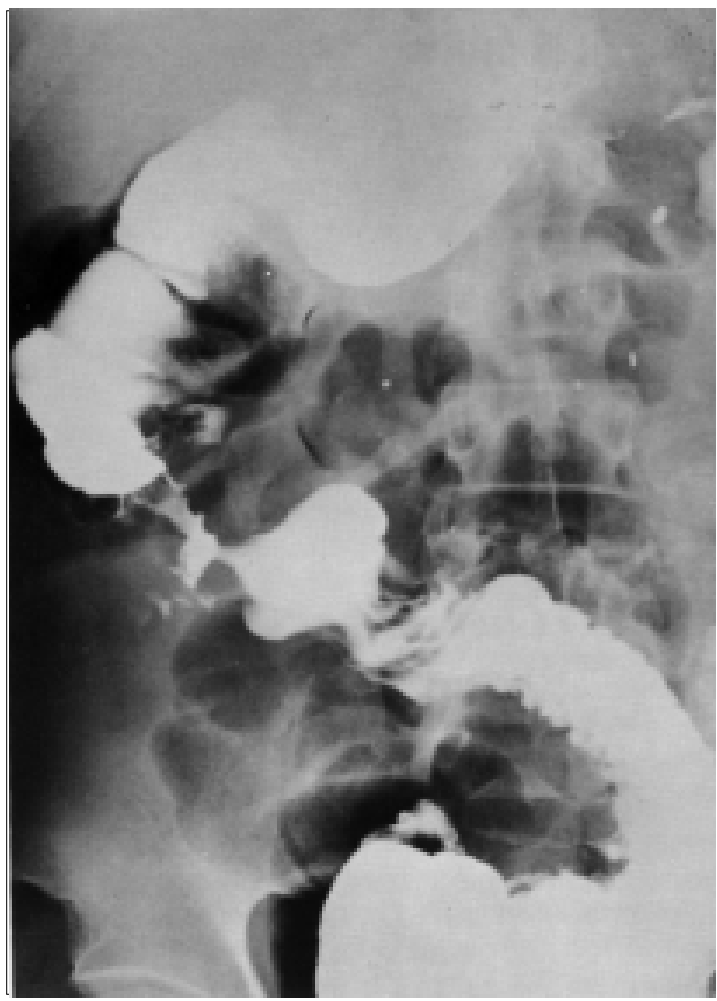

Figure 2 - Small bowel series: calcifications in ileocecal region; marked narrowing and ulcerations of the terminal ileum.

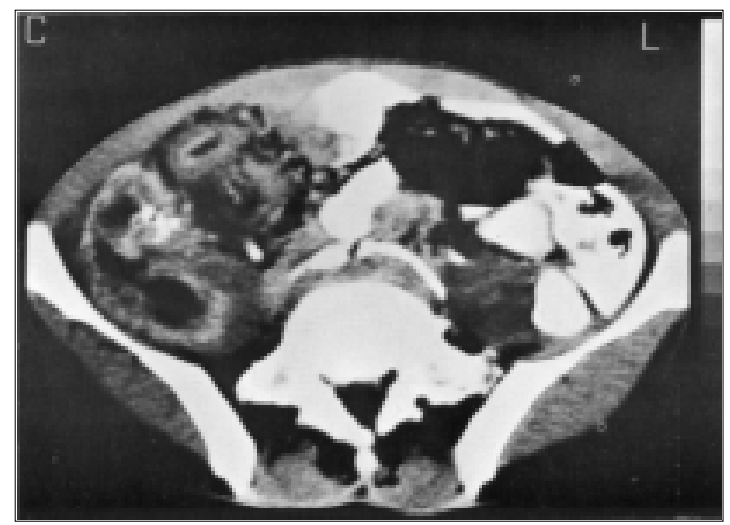

Figure 3 - CT scan aspect: abcessed area involving the psoas muscle, calcifications and thickening of bowel walls in the ileocecal area. 
The patient underwent a laparotomy, in which an iliocecal mass invading the anterior abdominal wall and the psoas muscle was observed. The patient was submitted to a right hemicolectomy, resection of the terminal ileum and of a part of the abdominal wall. A purulent secretion and necrotic material was observed at the level of the psoas. The surgical procedure was not considered curative for oncologic purposes.
The histologic study revealed PM, with suppurative areas in the psoas, multiple granulomas, neovascular vessels and active diffuse fibrosis with a pseudo tumor along the abdominal wall. The disease affected regional lymph nodes, and remaining structures were affected by typical reactional lymphoreticular hyperplasia. The patient was discharged on the eighth day after admission on ketoconazole, and still is undergoing treatment.

\section{DISCUSSION}

Paracoccidioidomycosis occurs mainly in adults, with a variety of clinical manifestations ${ }^{7}$. The intestinal form seems to be more common in the southeastern and central-western regions of $\mathrm{Brazil}^{7}$. There is a scarcity of intestinal findings in abdominal CT scans ${ }^{5}$. The main alterations in the intestinal tract are found in the small and large intestines, and in segments rich in lymphoid tissue, such as terminal ileum, appendix and right hemi-colon ${ }^{124}$. Radiographic findings are nonspecific, and may be confused with CRC, Crohn's Disease, other granulomatous diseases and lymphoma ${ }^{14}$. Abdominal findings are frequently described in patients with a previous history, or during the systemic evolution of the disease ${ }^{356}$.

An abdominal radiograph with intra-abdominal calcified masses may be suggestive of PM. The masses may be median, paramedian; round or irregular, frequently coalescing ${ }^{9}$. On barium studies, intestinal transit time may be increased, normal or slow; with segmental or multiple stenoses; an unorganized mucous relief in the region of the stenosis may be present; and there may be fistulae and perforation ${ }^{2348}$. Mucosal irregularities such as filling failures; narrowing, extrinsic compression and retraction of the colon are observed in the barium enema ${ }^{6}$; the main affected site is the right colon ${ }^{2}$, followed by the sigmoid and rectum ${ }^{6}$, and to a lesser degree by the transverse colon. Annular stenosis of distinct and smooth borders, due to extrinsic compression by the enlargement of mesenteric lymph nodes, is suggestive of $\mathrm{PM}^{24}$. Enlargement or calcifications of lymph nodes, dilation of the biliary tree, abscesses or spleen calcifications, enlargement or irregularity of the head of the pancreas, and abscesses of the psoas muscle observed on a CT scan are of great use for evaluating patients with this condition and for evaluating abdominal extension ${ }^{5}$.

Radiographic findings may be suggestive, although only mycological and histological confirmation defines the diagnosis. These patients up to the moment of diagnosis, as is the present case, are considered to be patients with neoplasia, and are frequently referred to oncological treatment. The present report emphasizes the signs present on X-rays (calcifications) that should be taken into consideration. CT scans increase findings, by showing enlargement of retroperitoneal lymph nodes and abscesses, interpreted, as signs of advanced and nonresectable neoplasia, should not discourage the surgeon.

\section{REFERENCES}

1. Avritchir Y, Perroni AA. Radiological manifestations of small intestinal South American blastomycosis. Radiology 127:607-609, 1978

2. Cunha MAR, Pereira AR, Gouvea OF, Pimentel JRL, Saad $M$, Teixeira D, Miyahira AR. Contribuição ao estudo radiológico da blastomicose sul-americana no aparelho digestivo. O Hospital 69:195-200, 1966.

3. Fonseca LC, Mignone C. Paracoccidioidomicose do intestino delgado: aspectos anátomo-clínicos e radiológicos de 125 casos. Revista do Hospital das Clínicas da Faculdade de Medicina de São Paulo 31:199207, 1976
4. Magalhães A. Paracoccidioidomicose (Blastomicose SulAmericana): aspectos radiológicos. Revista do Hospital das Clínicas da Faculdade de Medicina de São Paulo 35:147-155, 1980.

5. Martinez R, Bellucci AD, Fiorillo AM. A tomografia computadorizada na avaliação do comprometimento abdominal na paracoccidioidomicose. Revista da Sociedade Brasileira de Medicina Tropical 21:47-50, 1988.

6. Martinez R, Meneghelli UG, Dantas RO, Fiorillo AM. O comprometimento gastrointestinal na blastomicose sulamericana (paracoccidioidomicose). Revista da Associação Médica Brasileira 25:31-34, 1979. 
7. Montenegro MR, Franco M. Pathology. In: Franco M, Lacaz CS, Moreno AR, Del Negro G (eds) Paracoccidioidomycosis. $1^{\text {st }}$ edition, CRC Press, Boca Raton, p.131-150, 1994.

8. Moraes CR, Fiorillo AM, Costa JC. Lesões radiológicas intestinais na blastomicose sul-americana. O Hospital 71:145-156, 1967.

9. Rocha G, Roca R, Lacerda PR, Barbosa M, Lima EF. Blastomicose sul-americana ganglionar primitiva com calcificações abdominais. O Hospital 70:195-206, 1966.

10. Wanke B, Londero AT. Epidemiology and Paracoccidioidomycosis infection. In: Franco $\mathrm{M}$, Lacaz CS, Moreno AR, Del Negro G (eds) Paracoccidioidomycosis. $1^{\text {st }}$ edition, CRC Press, Boca Roton, p.109-120, 1994. 